\title{
OXIDATIVE STRESS IN BLAST-INDUCED ACUTE LUNG INJURY IS INDEPENDENT OF ENZYMATIC NITRIC OXIDE PRODUCTION
}

\author{
KOTUR-STEVULJEVIĆ JELENA*, SAVIĆ V**, PROKIĆ VERA**, STOJANOV MARINA* \\ and ČERNAK IBOLJA*** \\ *Faculty of Pharmacy, Belgrade, **Military Medical Academy, Belgrade, \\ *** Department of Neuroscience, Georgetown University, Washington, D.C., USA
}

(Received 1. April 2005)

Lung trauma has been considered to be one of the vital injuries induced by explosion-generated blast overpressure. Conflicting evidence exists as to whether nitric oxide plays a crucial role in acute lung injury induced by blast. Data presented in this study demonstrate that local exposure of mid-thoracic region to moderate-level blast overpressure significantly enhanced lipid peroxidation product malondialdehyde and superoxide anion generation in rabbit's lungs 30 minutes after exposure, whereas the activities of antioxidant enzymes (superoxide dismutase, glutathione peroxidase) activity showed parallel increase. $N^{G}$-nitro-Larginine methyl ester, a non-specific inhibitor of nitric oxide synthase (NOS), had no effects on the measured parameters suggesting that oxidative stress induced by blast exposure might be independent from NOS.

Key words: acute lung injury, blast injury, nitric oxide, oxidative stress

\section{INTRODUCTION}

Explosions of different origins may cause four major patterns of injury: 1) primary blast injury is caused by the blast wave itself; 2) secondary injury is caused by the fragments of debris propelled by the explosion; 3 ) tertiary injury is a result of the acceleration of whole or part of the body by the blast wind; 4) flash burns may occur as a consequence of the transient but intense heat of the explosion (Mellor, 1988). Primary blast injuries are in general characterized by the absence of external injuries, thus internal injuries are frequently unrecognized and their severity underestimated (Dedushkin et al., 1992). Exposure to blast overpressure has been considered to damage primarily gas-containing organs (i.e. ear, lungs) (Clemedson, 1956; Benzinger, 1950), causing a complex of injuries named blast injuries. There is a general agreement that spalling, implosion, inertia, and pressure differentials are the main mechanisms involved in the pathogenesis of blast injuries (Phillips, 1986; Chiffelle, 1966). In the case of lungs, it is assumed that the injury is caused by the propagation of the blast wave through the thoracic tissues resulting in the opposition of the lung to the chest wall, which does not respond to the blast wave as quickly as lungs do (Mayorga, 1997). Although the majority of investigations have focused on the mechanisms of 
blast-induced lung injuries (Brown et al., 1993; Elsayed et al., 1996; Guy et al., 1998), the exact mechanisms involved in secondary injury cascades still require clarification. Our previous studies suggest the involvement of leukotrienes (Cernak et al., 1996) and nitric oxide (Zunic et al., 2000) in the pathogenesis of acute lung damage following blast exposure. Recent studies report experimental evidence of blast-induced oxidative damage and antioxidant depletion in the rat lungs $1 \mathrm{~h}$ after exposure (Elsayed, 2003).

It is now well established that increased levels of reactive oxygen species (ROS) such as superoxide, hydroxyl and hydrogen peroxide among others, and their detrimental reactions with proteins, lipids, and DNA (Halliwell, 1996) play an important role in the pathophysiology of lung injury (Lang et al., 2002). On the other hand, ample evidence has demonstrated that an impaired balance between generation of ROS and the endogenous antioxidant system is among the essential factors determining the outcome of injury. The removal of reactive oxygen species is a dynamic and complex process that normally depends on numerous factors of enzymatic and nonenzymatic antioxidant systems. The enzymatic antioxidant system includes, among others, superoxide dismutase (SOD) as a specific scavenger for superoxide, and glutathione peroxidase (GSH$\mathrm{Px}$ ) and catalase that are specific for the hydrolysis of hydrogen peroxide and other lipid peroxides. It has been established that in pathologic conditions such as trauma, ROS production exceeds the capacity of the endogenous antioxidant system; thus the term "oxidative stress" is commonly used to define oxidative damage to cells and tissues caused by ROS with simultaneous dysfunction of antioxidant defense (Betteridge, 2000), immunological function (Walley et al., 1999), and neural signaling (Garthwaite, 1991). Additionally, NO is a highly reactive radical, which synthesis from L-arginine is mediated by nitric oxide synthase (NOS) (Squadrito, Pryor, 1998). Nitric oxide also plays an important role in ischemia/reperfusion-induced damage in the lungs (Kao SJ et al. 2003). The aim of this study was to investigate the role of NO in blast-induced oxidative stress in rabbit lungs after an early post-traumatic period.

\section{MATERIAL AND METHODS}

Protocols involving the use of animals were in compliance with the Guide for the Care and Use of Laboratory Animals published by NIH (DHEW publication NIH 85-23-2985).

Adult male rabbits $(2.5-3 \mathrm{~kg}, \mathrm{n}=20$ ) were anesthetized (Ketamine $\mathrm{HCl} 40$ $\mathrm{mg} / \mathrm{kg}$ Acepromazine maleate $1-2 \mathrm{mg} / \mathrm{kg}$, im) and implanted with femoral venous and arterial catheters. Blood pressure and ECG were continuously monitored, as well as the respiratory rate using a tachometer triggered by chest movement. Rabbits were randomly divided into three groups of 7 each: 1) the control group was exposed to the same conditions and procedures as the experimental group except for blast exposure; 2 ) animals in the blast group were subjected in the right mid-thoracic region to blast overpressure $(304 \mathrm{kPa})$ via an air-driven shock tube (Cernak et al., 1995). The injury sustained was defined by gross pathologic examination as moderate pulmonary injury (i.e. 4 pulmonary contusions 
characterized as confluent ecchymosis extending over approximately $30 \%$ of the lung tissue); 3) animals received $30 \mathrm{mg} / \mathrm{kg} \mathrm{N}^{\mathrm{G}}$-nitro-L-arginine methyl ester (LNAME; dissolved in $1 \mathrm{ml}$ of saline; Sigma, St. Louis, MO) intravenously immediately after being subjecti to blast exposure.

Blood samples were collected in heparinized tubes, at 30 minutes posttrauma, kept on ice, centrifugated at $+4^{\circ} \mathrm{C}$, plasma separated and kept at $-80^{\circ} \mathrm{C}$ until the assay was carried out. Lung tissue was taken from two distinct regions: mediastinal (named as "bronchial") and costal (named as "alveolar") parts. Samples were immediately immersed into liquid nitrogen and stored at $-80^{\circ} \mathrm{C}$ for measurements of the lipid peroxidation product malondialdehyde (MDA), superoxide anion generation $\left(\mathrm{O}_{2}{ }^{-}\right)$, and activities of antioxidant enzymes (SOD and GSH-Px). The degree of lipid peroxidation in plasma and lung tissue was estimated by malondialdehyde assay as described previously (Takeda et al., 1986). Total sulfhydril (SH) groups content in plasma was determined by Ellmann's assay using 0.2 mM 5,5'-dithiobis(2-nitrobenzoic acid) (DTNB) (Ellman, 1952). The generation of superoxide anion radicals in lung samples was measured using the $\mathrm{O}_{2}$. ${ }^{-}$- mediated NBT reduction as previously described by Auclair and Voisin (Auclair, Voisin, 1985). Superoxide dismutase activity (EC 1.15.1.1) was measured by spectrophotometric assay, based on the ability of SOD to inhibit the auto-oxidation of epinephrine at alkaline $\mathrm{pH}$ (Misra, Fridovich, 1972, Sun, Zigman, 1978). Glutathione peroxidase (EC 1.11.1.9) activity was estimated by the method of reduced glutathione (GSH) oxidation, mediated by GSH-Px using NADPH (Flohe and Gunzler, 1984).

Values are expressed as mean $\pm \mathrm{SE}$. Analysis of variance followed by t-test with Bonferroni corrections for multiple comparisons were used for comparisons of blast-injured (treated or non-treated) and control groups; $p<0.05$ was considered to reflect a statistically significant difference.

\section{RESULTS}

Local (chest) exposure to blast overpressure, under the conditions described above, caused pathological changes such as petechiae, ecchymoses, bleb, and isolated and rarely confluent hemorrhages in trachea and lungs. This pulmonary blast injury was characterized as of moderate severity, where the pathological changes extended over approximately $30 \%$ of the lung tissue.

A statistically significant increase in plasma MDA production of $3.98 \pm 0.3$ $\mathrm{mol} / \mathrm{L}$ vs. control $(2.12 \pm 0.2 \mathrm{~mol} / \mathrm{L})$ as presented in Fig. $1 \mathrm{~A})$ was parallel to the decrease in anti-oxidant SH groups (0.24 \pm 0.015 vs. $0.38 \pm 0.025 \mathrm{mmol} / \mathrm{L}$; Fig. $1 \mathrm{~B})$ and demonstrated the development of systemic oxidative stress during the early post-traumatic period. Both increase in MDA and decrease in SH groups were prevented by L-NAME administration (Fig. 1).

Changes in MDA concentration in rabbit's lung structures at 30 minutes after blast injury are presented in Fig.2. MDA was significantly increased in both bronchiolar (5.8 $\pm 1.14 \mathrm{~mol} / \mathrm{g}$ proteins) and alveolar $(3.78 \pm 0.56 \mathrm{~mol} / \mathrm{g}$ proteins) parts of lung parenchyma compared to the control $(1.53 \pm 0.27$ and $1.15 \pm 0.15 \mathrm{~mol} / \mathrm{g}$ proteins, respectively). Treatment with L-NAME did not 
significantly modify these changes (Fig. 2). The exposure to blast overpressure caused statistically significant increase in superoxide anion radical generation in both alveolar (41.2 $\pm 3.86 \mathrm{~mol} \mathrm{NBTred} . / \mathrm{min} / \mathrm{g}$ proteins) and bronchiolar ( 38.56 $\pm 3.77 \mathrm{~mol} \mathrm{NBTred} . / \mathrm{min} / \mathrm{g}$ proteins) compared to control values $(27.7 \pm 2.9$ and $25.1 \pm 2.9 \mathrm{~mol} \mathrm{NBT}$ red./min/g proteins, respectively). L-NAME administered immediately after injury had no effect on blast-induced $\mathrm{O}_{2}{ }^{-}$- generation (Fig. 3).

A.

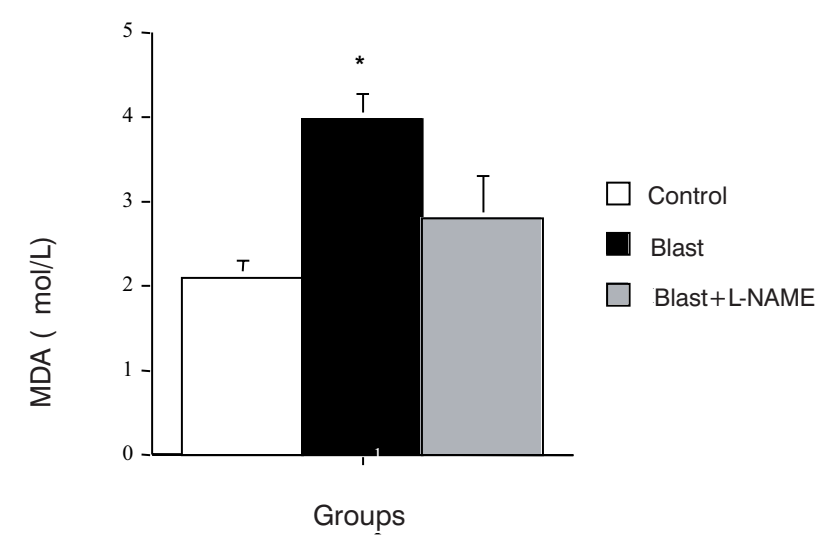

B.

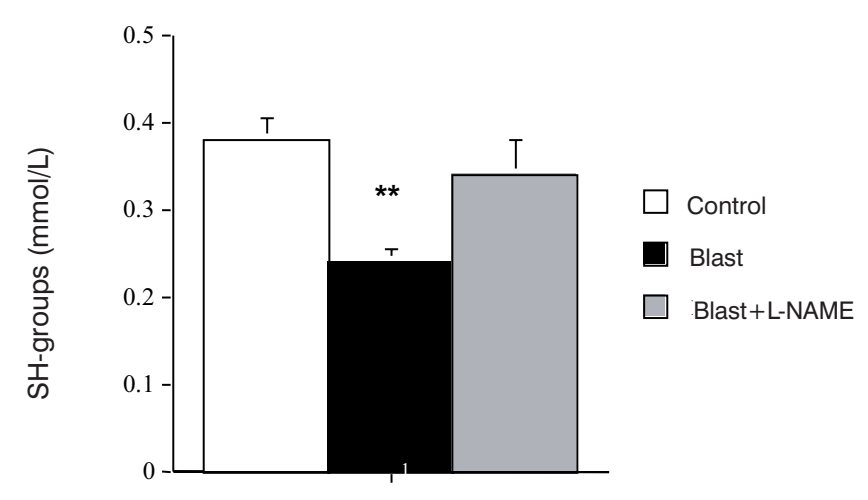

Groups

Figure 1. Changes in plasma malondialdehyde (MDA) concentration expressed as $\mathrm{mol} / \mathrm{L}$ (A) and anti-oxidant sulfhydril group concentration expressed as $\mathrm{mmol} / \mathrm{L}$ (B) at 30 minutes after blast exposure. Injured (Blast and Blast+L-NAME) animals were compared to non-injured animals (Control) receiving vehicle. Blast+L-NAME rabbits received $30 \mathrm{mg} / \mathrm{kg}$ L-NAME administered intravenously immediately after blast exposure. Results are shown as mean \pm S.E.M. ${ }^{\star} p<0.05$ and ${ }^{\star *} p<0.01$ vs. Control 


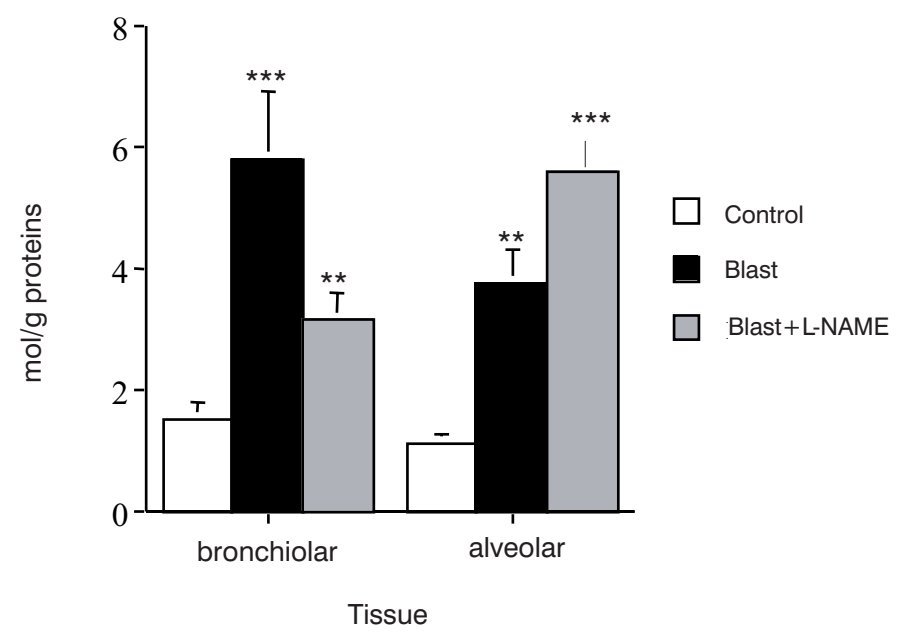

Figure 2. Changes in malondialdehyde production (MDA; mol/g proteins) measured in bronchiolar and alveolar regions of lungs at 30 minutes after blast exposure. Injured (Blast and Blast+L-NAME) animals were compared to non-injured animals (Control) receiving vehicle. Blast+L-NAME rabbits received $30 \mathrm{mg} / \mathrm{kg}$ L-NAME administered intravenously immediately after blast exposure. Results are shown as mean \pm S.E.M. ${ }^{* *} p<0.01$ and ${ }^{* * *} p<0.001$ vs. Control

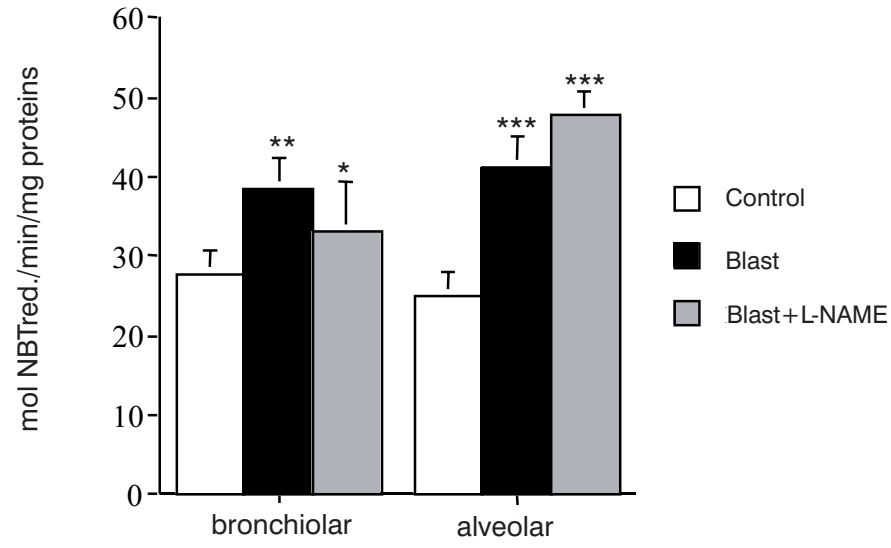

Tissue

Figure 3. Superoxide anion radical generation $\left(\mathrm{O}_{2} \cdot-\right.$; mol NBTred./min/g proteins) measured in bronchiolar and alveolar regions of lungs at 30 minutes after blast exposure. Injured (Blast and Blast+L-NAME) animals were compared to non-injured animals (Control) receiving vehicle. Blast+L-NAME rabbits received $30 \mathrm{mg} / \mathrm{kg} \mathrm{L}$ NAME administered intravenously immediately after blast exposure. Results are shown as mean \pm S.E.M. ${ }^{* \star} p<0.01$ and ${ }^{* * *} p<0.001$ vs. Control 


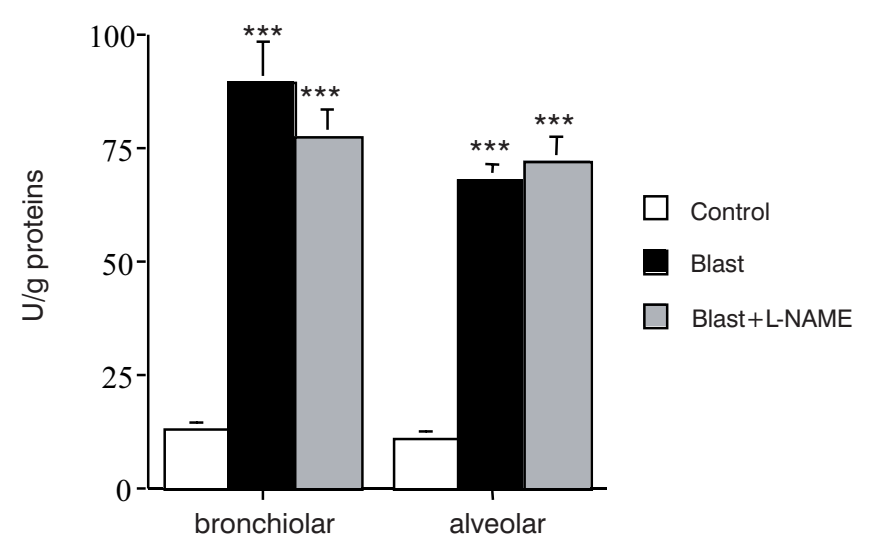

Tissue

Figure 4. Superoxide dismutase activity (SOD; expressed as $\mathrm{U} / \mathrm{g}$ proteins) measured in bronchiolar and alveolar regions of lungs at 30 minutes after blast exposure. Injured (Blast and Blast+L-NAME) animals were compared to non-injured animals (Control) receiving vehicle. Blast $+\mathrm{L}-\mathrm{NAME}$ rabbits received $30 \mathrm{mg} / \mathrm{kg} \mathrm{L}-\mathrm{NAME}$ administered intravenously immediately after blast exposure. Results are shown as mean \pm S.E.M. $\star \star \star p<0.001$ vs. Control

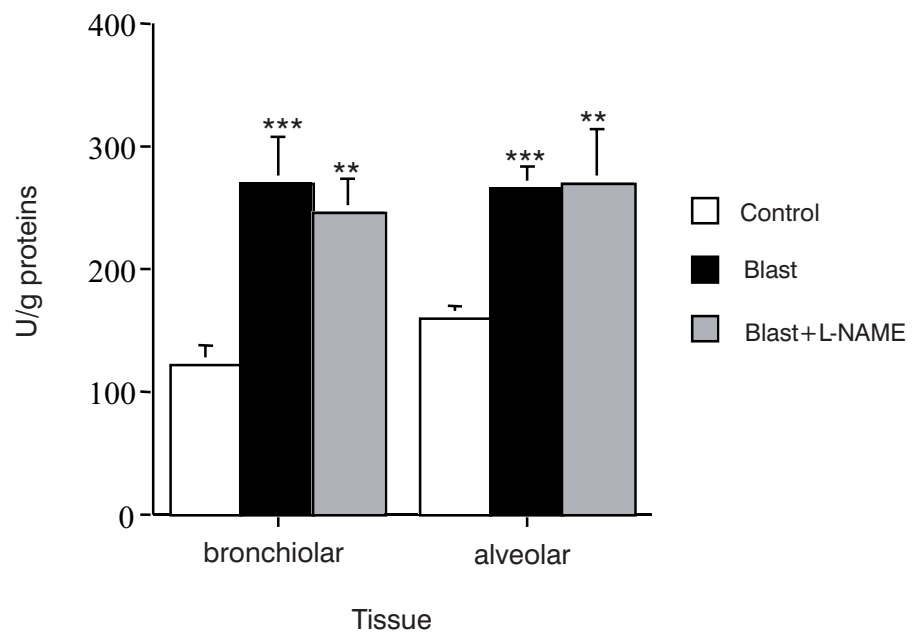

Figure 5. Glutathione peroxidase activity (GSH-Px; expressed as U/g proteins) measured in bronchiolar and alveolar regions of lungs at 30 minutes after local blast exposure. Injured (Blast and Blast+L-NAME) animals were compared to non-injured animals (Control) receiving vehicle. Blast+L-NAME rabbits received $30 \mathrm{mg} / \mathrm{kg}$ L-NAME administered intravenously immediately after blast exposure. Results are shown as mean \pm S.E.M. ${ }^{* *} p<0.01$ and ${ }^{* * *} p<0.001$ vs. Control 
Results of SOD activity in lung parenchyma of animals subjected to local blast exposure are presented in Fig. 4. In comparison with the controls (bronchiolar: $13.07 \pm 1.77$ and alveolar: $11.34 \pm 1.53 \mathrm{U} / \mathrm{g}$ proteins), total SOD activity was significantly increased in both pulmonary regions $(77.70 \pm 6.2$ and $72.11 \pm 5.66 \mathrm{U} / \mathrm{g}$ proteins, respectively) at 30 minutes post-trauma. These changes remained unchanged by L-NAME. Alterations in GSH-Px activity are summarized in Figure 5. The GSH-Px activity in the control group was $123.51 \pm$ $14.83 \mathrm{U} / \mathrm{g}$ proteins in bronchiolar region and $160.50 \pm 10.05 \mathrm{~mol} \mathrm{U} / \mathrm{g}$ proteins in alveolar part of lung parenchyma. After injury, a significant increase in GSH-Px activity occurred in both lung structures examined (271 $47 \pm 38.3$ and $267.13 \pm$ $18.75 \mathrm{U} / \mathrm{g}$ proteins, respectively); treatment with L-NAME did not alter such an increase.

\section{DISCUSSION}

It has been established that production of ROS is one of the common secondary effects initiated by injury (McCord, 1993). Extensive membrane lipid peroxidation induced by trauma involves ROS attack on double bonds of unsaturated fatty acids in membrane phospholipids. Hydroxyl radical $(\mathrm{OH})$, hydrogen peroxide $\left(\mathrm{H}_{2} \mathrm{O}_{2}\right)$, peroxynitrite $\left(\mathrm{ONOO}^{-}\right)$, and superoxide anion radical $\left(\mathrm{O}_{2}{ }^{-}\right)$have been shown as major initiators of membrane lipid peroxidation (Toyokuni, 1999). Additionally, among the numerous mechanisms that are capable of inducing generation of ROS are inflammation, stimulation of nitric oxide synthase and xanthine oxidase, as well as mitochondrial dysfunction and excitotoxic insults (Gutteridge and Halliwell, 2000). Iron delocalization induced by superoxide, acidosis and hypoxia can also contribute to oxidative stress (Ying et al., 1999). Previous studies have been demonstrated that blast exposure leads to oxidative stress development including an increase in lipid peroxidation and depletion of anti-oxidant factors in the rat lungs (Elsayed et al., 1996, Elsayed, Gorbunov, 2003). These results strongly support our findings. Our results show a significant increase in superoxide anion generation and lipid peroxidation product MDA in the lungs early after blast exposure. A prompt post-traumatic burst in $\mathrm{O}_{2}$.production was reported after various models of acute lung injury (Lu et al., 2002, Midorikawa et al., 2003). Increase in both SOD and GSH-Px activitivites, i.e. enhanced enzymatic anti-oxidant defense, may be a part of post-traumatic compensatory mechanisms related to the inhibition/delay of injury-induced cell death. The fact that there were no significant differences in parameters measured both in bronchiolar and alveolar regions, suggests that the propagation of the blast wave, i.e. the distribution of delivered kinetic energy, evenly affected all lung structures.

Enhanced NO levels in the blood following experimental blast exposure have been demonstrated previously (Elsayed and Gorbunov, 2003, Zunic et al., 2000). Interestingly, Elsayed and Gorbunov (Elsayed NM, Gorbunov NV, 2003) hypothesized that increased NO content in blood and tissue (although they did not measured NO concentration in the lungs) reflects the antioxidant property of NO by which NO prevents propagation of free radical-mediated reactions via 
blocking oxoferryl hemoglobin formation through redox reactions. In our study, inhibition of NO production by L-NAME prevented the increase in MDA and decrease in anti-oxidant SH groups in the blood of rabbits subjected to blast injury, suggesting that NO might contribute to blast-induced systemic changes.

Numerous experimental studies of acute lung injury (Kao et al., 2003; Nagata et al., 2003; Wang et al., 1999) have reported an increased content of NO, presence of inducible NOS (iNOS) and nitrotyrosine, markers of peroxynitrite tissue damag, in alveolar spaces, which implied that NO produced via NOS may play a significant role in the pathogenesis of acute pulmonary damage. It has been shown that NO generated by iNOS interacts with ROS derived from neutrophils and macrophages and forms peroxynitrite (Lang et al., 2002), a potent oxidant that induces extensive tyrosine nitration and subsequent production of nitrotyrosine (Squadrito and Pryor, 1998). Ample evidence has demonstrated that NO formation independent from NOS occurs in biological systems under acidic conditions such as ischemia or shock (Zweier JL et al., 1999). This NO generation, which occurs via disproportionation or reduction of nitrite to NO, is not blocked by NOS inhibitors (Zweier et al., 1995). The NOS-independent pathway has been reported as the major source of NO in post-ischemic tissues (Zweier et al., 1999). Damage to the lungs induced by blast exposure includes pulmonary hemorrhage, rupture of alveolar septa and edema, leading to the condition of reduced oxygenation of blood and organs/organ systems. Thus, non-enzymatic NO synthesis in the lungs is most likely the predominant way of excessive NO formation following blast exposure, which could explain the lack of L-NAME to modify the blast-induced oxidative stress.

This study has demonstrated that local blast exposure causes oxidative stress in the lungs, which also manifests by increased MDA and decreased antioxidant $\mathrm{SH}$ groups in the blood during the early post-traumatic period. Such a condition suggests systemic hypoxia. However, the lack of L-NAME to modify oxidative stress in the lungs could be explained by NOS-independent NO generation that occurs under acidic/ischemic conditions caused by blast overpressure. These results suggest potential therapeutic directions including anti-oxidants in blast-induced acute lung injury.

ACNKOWLEDGMENT:

We acknowledge Vesna Savic for her outstanding technical assistance.

\author{
Address for Correspondence: \\ Jelena Kotur - Stevuljevic \\ Institute of Medical Biochemistry \\ Faculty of Pharmacy \\ Vojvode Stepe 450, P.Box 146 \\ 11000 Belgrade \\ Serbia\&Montenegro \\ E-mail: jkotur@pharmacy.bg.ac.yu
}




\section{REFERENCES}

1. Auclair C, Voisin E, 1985, Nitroblue-tetrazolium reduction. In: Greenwald RA, eds. Handbook of methods for oxygen radical research, Boca Raton: CRC Press, Inc, 123-32.

2. Benzinger T, 1950, Physiological effects of blast in air and water. In: eds. German Aviation Medicine, World War II. Washington DC: Department of the Air Force, 1225-9.

3. Betteridge DJ, 2000, What is oxidative stress? Metabolism, 49, 3-8.

4. Brown RF, Cooper GJ, Maynard RL, 1993, The ultrastructure of rat lung following acute primary blast injury, Int J Exp Pathol, 74, 151-62.

5. Cernak I, Radosevic P, Malicevic Z, Savic J, 1995, Experimental magnesium depletion in adult rabbits caused by blast overpressure, Magnes Res, 8, 249-59.

6. Cernak I, Savic J, Malicevic Z, Zunic G, Radosevic P, Ivanovic I,1996, Leukotrienes in the pathogenesis of pulmonary blast injury, J Trauma, 40, S148-51.

7. Chiffelle TL, 1966, Pathology of direct air-blast injury, In: eds. Technical Progress Report DA-49-146XY-055. Washington DC: Defense Atomic Support Agency, Department of Defense;

8. Clemedson CJ, 1956, Blast injury, Physiol Rev, 36, 336-54.

9. Dedushkin VS, Kosachev ID, Tkachenko SS, Shapovalov VM, 1992, Rendering medical care and the volume of the treatment of victims with blast injuries (a review of the literature), Voen Med $\mathrm{Zh}$, 13-8.

10. Ellman GL, 1952, Tissues sulfhydril groups, Arch Biochem Biophys, 82, 70-7.

11. Elsayed NM, Tyurina YY, Tyurin VA, Menshikova EV, Kisin ER, Kagan VE, 1996, Antioxidant depletion, lipid peroxidation, and impairment of calcium transport induced by air-blast overpressure in rat lungs, Exp Lung Res, 22, 179-200.

12. Elsayed NM, Gorbunov NV, 2003, Interplay between high energy impulse noise (blast) and antioxidants in the lung, Toxicology, 189, 63-74.

13. Flohe L, Gunzler WA, 1984, Assays of glutathione peroxidase, Methods Enzymol, 105, 114-21

14. Furchgott RF, 1996, The 1996 Albert Lasker Medical Research Awards. The discovery of endothelium-derived relaxing factor and its importance in the identification of nitric oxide, JAMA, 276, 1186-8.

15. Garthwaite J, 1991, Glutamate, nitric oxide and cell-cell signalling in the nervous system, Trends Neurosci, 14, 60-7.

16. Gutteridge JM, Halliwell B, 2000, Free radicals and antioxidants in the year 2000. A historical look to the future, Ann N Y Acad Sci, 899, 136-47.

17. Guy RJ, Glover MA, Cripps NP,1998, The pathophysiology of primary blast injury and its implications for treatment, Part I: The thorax. J R Nav Med Serv, 84, 79-86.

18. Halliwe/l $B$, 1996, Free radicals, proteins and DNA: oxidative damage versus redox regulation, Biochem Soc Trans, 24, 1023-7.

19. Kao SJ, 2003, Nitric oxide mediates lung injury induced by ischemia-reperfusion in rats, J Biomed Sci, 10, 58-64.

20. Lang JD, McArdle PJ, O'Reilly PJ, Matalon S, 2002, Oxidant-antioxidant balance in acute lung injury, Chest, 122, 314S-20S.

21. Lu W, Chen Y, Xia Z, 2002, Direct detection of oxygen free radicals produced in the viscera of burned rats using electron paramagnetic resonance spectroscopy, Chin J Traumatol, 5, 118-20.

22. Mayorga MA, 1997, The pathology of primary blast overpressure injury, Toxicol, 121, 17-28.

23. McCord JM, 1993, Human disease, free radicals, and the oxidant/antioxidant balance, Clin Biochem, 26, 351-357.

24. Mellor SG, 1988, The pathogenesis of blast injury and its management, Br J Hosp Med, 39, 536-9.

25. Midorikawa J, Maehara K, Yaoita H, Watanabe T, Ohtani H, Ushiroda S et al. 2001, Continuous observation of superoxide generation in an in-situ ischemia-reperfusion rat lung model, Jpn Circ J, 65, 207-12.

26. Misra HP, Fridovich I, 1972, The role of superoxide anion in the autoxidation of epinephrine and a simple assay for superoxide dismutase, J Biol Chem, 247, 3170-80. 
27. Nagata K, Iwasaki Y, Takemura Y, Harada H, Yokomura I, Fushiki S et al. 2003, Effect of inhaled NGnitro-L-arginine methyl ester on Candida-induced acute lung injury, Chest, 124, 2293-301.

28. Phillips YY, 1986, Primary blast injuries, Ann Emerg Med; 15, 1446-50.

29. Sun M, Zigman S, 1978, An improved spectrophotometric assay for superoxide dismutase based on epinephrine autoxidation, Anal Biochem, 90, 81-9.

30. Takeda K, Shimada Y, Okada T, Amano M, Sakai T, Yoshiya I, 1986, Lipid peroxidation in experimental septic rats, Crit Care Med, 14, 719-23.

31. Toyokuni S, 1999, Reactive oxygen species-induced molecular damage and its application in pathology, Pathol Int, 49, 91-102.

32. Squadrito GL, Pryor WA, 1998, Oxidative chemistry of nitric oxide: the roles of superoxide, peroxynitrite, and carbon dioxide, Free Radical Biol Med, 25, 392-403.

33. Walley KR, McDonald TE, Higashimoto Y, Hayashi S, 1999, Modulation of proinflammatory cytokines by nitric oxide in murine acute lung injury, Am J Resp Crit Care Med, 160, 698-704.

34. Wang D, Wei J, Hsu K, Jau J, Lieu MW, Chao TJ, Chen HI, 1999, Effects of nitric oxide synthase inhibitors on systemic hypotension, cytokines and inducible nitric oxide synthase expression and lung injury following endotoxin administration in rats, J Biomed Sci, 6, 28-35.

35. Ying W, Han S-K, Miller JW, Swanson RA,1999, Acidosis potentiates oxidative neuronal death by multiple mechanisms, J Neurochem, 73, 1549-56.

36. Zunic G, Pavlovic R, Malicevic Z, Savic V, Cernak I, 2000, Pulmonary blast injury increases nitric oxide production, disturbs arginine metabolism, and alters the plasma free amino acid pool in rabbits during the early posttraumatic period, Nitric Oxide, 4, 123-128.

37. Zweier JL, Samouilov A, Kuppusamy P, 1999, Non-enzymatic nitric oxide synthesis in biological systems, Biochim Biophys Acta, 1411, 250-62.

38. Zweier JL, Wang P, Samouilov A, Kuppusamy P, 1995, Enzyme-independent formation of nitric oxide in biological tissues, Nat Med, 1, 804-9.

\title{
OKSIDATIVNI STRES U AKUTNOJ BLAST POVREDI PLUĆA JE NEZAVISAN OD ENZIMSKE SINTEZE AZOT-MONOKSIDA
}

\author{
KOTUR-STEVULJEVIĆ JELENA, SAVIĆ V, PROKIĆ VERA, STOJANOV MARINA \\ i ČERNAK IBOLJA
}

\section{SADRŽAJ}

Smatra se da je povreda pluća jedna od najvažnijih povreda do kojih dolazi delovanjem blast talasa generisanog na mestu eksplozije. Do danas ne postoji definitivan stav da li azot-monoksid ima bitnu ulogu u akutnoj blast povredi pluća. Rezultati ove studije pokazuju da lokalno delovanje blast nadpritiska srednje jačine na središnji deo toraksa dovodi do povećanog stvaranja malondialdehida, produkta lipidne peroksidacije kao i povećanog generisanja superoksidnog anjona, 30 minuta posle traume. Istovremeno, dolazi do smanjenja aktivnosti antioksidativnih enzima (superoksid-dizmutaze i glutation-peroksidaze) u plućnom tkivu kunića. $N^{G}$-nitro-L-arginin-metil estar (L-NAME), nespecifični inhibitor enzima azot-monoksid sintaze (NOS), nije imao efekta na određivane parametere, što ukazuje da je oskidativni stres indukovan blast povredom verovatno nezavisan od aktivnosti enzima NOS. 